\title{
Imagens da(s) fronteira(s) em livros didáticos de geografia brasileiros e argentinos: o que existe além dos muros?
}

Flaviana Gasparotti Nunes

Programa de Pós-Graduação em Geografia, Faculdade de Ciências Humanas, Universidade Federal da Grande Dourados, Brasil.

Recibido: 2 de marzo de 2018. Aceptado: 2 de agosto de 2018.

\begin{abstract}
Resumo
Neste artigo tivemos como objetivo analisar de que maneira as imagens presentes nos livros didáticos de Geografia utilizados no Brasil e na Argentina contribuem para a construção de determinada(s) concepção(ões) de fronteira. Priorizamos a análise das imagens fotográficas, pois a partir de pesquisa realizada nesses materiais identificamos o predomínio destas, embora também compareçam mapas e esquemas - entre outras - porém, em número inferior às fotografias. Dentre as conclusões, podemos apontar que as imagens fotográficas presentes nos livros didáticos de Geografia brasileiros e argentinos contribuem para a construção e fixação da ideia de fronteira como limite, barreira, separação de lados, bastante associado ao caráter estatal, burocrático e controlador da mobilidade das pessoas. Mesmo nos textos didáticos que intencionam trazer uma compreensão da fronteira no sentido dos contatos e integração, as imagens utilizadas são vias de acesso (estradas e pontes) nas quais está mais presente o aspecto comercial do que de intercâmbios culturais, sociais e humanos não associando fronteira à questão das identidades e diferenças.
\end{abstract}

PALAVRAS-CHAVE: FRONTEIRA. LIVROS DIDÁTICOS. IMAGENS. GEOGRAFIA ESCOLAR.

\section{Images of the frontie(s) in brazilian and argentine textbooks of geography: what exists beyond the walls?}

\begin{abstract}
This paper presents partial results of a research that had the objective to analyze how the images presented in Geography textbooks used in Brazil and Argentina contribute to the construction of certain understanding of the concept of border. The research verified the predominance of photographic images, although also the appearance of maps and schemes -among others- but in a lower number than photographs. Among the conclusions, we point out that the photographic images displayed in brazilian and argentine textbooks of geography reinforce the construction and fixation of the idea of frontier as border, barrier or separation of sides quite associated with the state
\end{abstract}


character, bureaucratic and controller of the mobility of people. Even in the didactic texts that intend to bring an understanding of the frontier in the sense of contacts and integration, the images used are access roads (roads and bridges) in which the commercial aspect is more relevant than the cultural, social and human exchanges, not associating the frontiers to the question of identities and differences.

KEYWORDS: BORDER. TEXTBOOKS. IMAGES. SCHOOL GEOGRAPHY.

PALABRAS CLAVE: FRONTERA. LIBROS ESCOLARES. IMÁGENES. GEOGRAFÍA ESCOLAR.

\section{Introdução}

Partindo da relevância que a problemática em torno da(s) fronteira(s), bem como das imagens têm adquirido na atualidade, neste artigo, trazemos parte dos resultados de uma pesquisa que teve como objetivo analisar de que maneira as imagens presentes nos livros didáticos de Geografia utilizados no Brasil e na Argentina contribuem para a construção de determinada(s) concepção(ões) de fronteira. ${ }^{1}$

Para isso, realizamos um estudo dos livros didáticos de Geografia utilizados no Brasil e na Argentina, de forma a buscar possíveis semelhanças e/ou diferenças entre esses materiais no que concerne à(s) ideia(s) de fronteira construída(s) por meio das imagens presentes nesses livros. Como o estudo não teve como objetivo analisar as formas de trabalho desenvolvidas pelos professores com esses materiais, nosso foco neste artigo centrou-se apenas na discussão sobre o potencial das imagens, notadamente as fotográficas, como linguagens que potencializam determinadas ideias e concepções sobre fronteira.

O texto está organizado em três partes. Inicialmente, trazemos algumas questões e referências teóricas no intuito de problematizar a ideia de fronteira e evidenciar nossa compreensão sobre esse conceito. Num segundo momento, procuramos destacar a importância e papel que as imagens têm desempenhado para construir pensamentos e compreensões sobre mundo, principalmente no âmbito da Geografia escolar. Dentre essas imagens discutimos especialmente a fotografia pelo fato de ser o tipo de imagem identificada com maior frequência nos capítulos/conteúdos que tratam da/sobre a fronteira nos livros didáticos pesquisados. No terceiro momento, apresentamos e analisamos algumas fotografias encontradas na pesquisa realizada. Nessa análise identificamos similitudes e elementos que mais aproximam do que distanciam as concepções ou imaginários sobre a fronteira construídos pela Geografia escolar no Brasil e na Argentina.

\section{Fronteiras: quando se estabelecem as diferenças}

Mesmo que tradicionalmente a ideia de fronteira esteja associada a uma dimensão de barreira e fixidez, agindo como elemento diferenciador e separador, pode também instigar a relação de estruturas socioespaciais distintas, estabelecendo interações e constituindo realidades dinâmicas que representam um campo de práticas sociais,

1 A pesquisa em questão foi desenvolvida em nosso estágio de pós-doutorado realizado junto ao Instituto de Geografia "Romualdo Ardissone", Facultad de Filosofía y Letras da Universidade de Buenos Aires, sob direção da Dra. Verónica Hollman no período de abril/2017 a março/2018. 
políticas, econômicas e culturais que evocam conflitos e tensões inerentes aos sujeitos nelas localizados. Nesta direção “(...) planteamos la frontera como un lugar difuso que no se restringe a las limitaciones geográficas, sino que se amplía a todos los espacios donde se encuentran las diferencias y surgen posibilidades de conocimiento, convivencia y colaboración entre dos o más realidades diferentes" (Barroso, 2017: 6).

As tentativas de se conceituar de forma rigorosa a ideia de fronteira são corrompidas pelas próprias condições que o viver em áreas fronteiriças provoca. Dessa maneira, tanto aqueles que entendem a fronteira como divisão fixa quanto os que se antepõem a esse entendimento e entendem a fronteira como contato e trocas, são forçados pela própria dinâmica da realidade fronteiriça a vislumbrar algo mais nesse conceito, mesclando os entendimentos de fronteira como divisão e como contato.

Segundo Albuquerque (2010), apesar da fixação do limite, as fronteiras nacionais estão em movimento o que pode ser percebido pelos fluxos migratórios, estratégias geopolíticas, influências econômicas e culturais, circulação de mercadorias etc. Nesta direção, Mellado (2008: 40) aponta duas características que se destacam na análise da fronteira como fato espacial: “(...) por un, sus desplazamientos reales o virtuales revelan los deseos nacionales por controlar y extender la mayor territorialidad posible y, por otro, sus constantes movimientos muestran tanto su inestabilidad como su arbitrariedad".

O caráter dinâmico, flexível e arbitrário das fronteiras nacionais assinalado por esses autores, permite-nos afirmar que não existe fronteira ou fronteiras em abstrato, existem situações sociais e singulares de fronteiras -as fronteiras são fenômenos sociais, plurais e dinâmicos ${ }^{2}$ (Albuquerque, 2010).

Raffestin (2005: 10), por sua vez, afirma que "(...) a fronteira vai muito mais além do fato geográfico que ela realmente é, pois ela não é só isso". O autor amplia a análise sobre a concepção hegemônica de fronteira, destacando que além de espaço-temporal, a fronteira também é biossocial: "A fronteira não é uma linha, a fronteira é um dos elementos da comunicação biossocial que assume uma função reguladora. Ela é a expressão de um equilíbrio dinâmico que não se encontra somente no sistema territorial, mas em todos os sistemas biossociais" (Raffestin, 2005: 13).

Ao destacar a fronteira como expressão de um equilíbrio dinâmico que não se restringe ao sistema territorial, a proposição de Raffestin aproxima-se das ideias de Martins (1997) para quem a fronteira é um lugar em que os vários grupos humanos, ali localizados, produzem diversos tempos históricos, ou seja, uma geografia que manifesta os desencontros temporais da história: "O desencontro na fronteira é o desencontro de temporalidades históricas, pois cada um desses grupos está situado diversamente no tempo da História" (Martins, 1997: 151).

2 No sentido de reforçar a compreensão das fronteiras como fenômenos sociais, plurais e dinâmicos, destacamos a análise de Zusman (2017) sobre o papel da técnica na configuração das fronteiras latino-americanas entre os séculos XVII e XIX e na passagem do século XX para o XXI. A autora demonstra que na atualidade a técnica participa no reforçamento das fronteiras de alguns Estados nacionais e também na criação de outras que não necessariamente coincidem com os confins dos territórios dos Estados. Procedimentos como o controle de mobilidade de caráter biométrico adquirem papel ativo na colonização de novas áreas ao multiplicar as fronteiras do mundo atual, conduzindo a uma domesticação dos corpos na medida em que, a partir desses procedimentos, a informação sobre os corpos é codificada e circula em distintas escalas regionais, nacionais e globais. 
A fronteira é o território de invenção do outro, onde o indivíduo procura se reconhecer frente aquilo que é imposto ou aceito como o único e aquilo que vivencia como alteridade e diferenças. Essa alteridade decorre do fato de que o outro possui uma temporalidade, por conseguinte uma história, diferente da nossa.

Martins (1997: 150) toma a fronteira como lugar da alteridade, de conflitos entre encontros e desencontros:

(...) a fronteira é essencialmente o lugar da alteridade. É isso o que faz dela uma realidade singular. A primeira vista é o lugar do encontro dos que por diferentes razões são diferentes entre si, como os índios de um lado e os civilizados de outro; como os grandes proprietários de terra, de um lado, e os camponeses pobres, de outro. Mas o conflito faz com que a fronteira seja essencialmente, a um só tempo, um lugar de descoberta do outro e de desencontro.

Esse desencontro de temporalidades instaura a consciência de que não existe só uma linha, ritmo e evolução histórica, aquela que entendemos como nossa. Eis um dos grandes entraves no processo de aceitação do outro, ou seja, entender e respeitar que numa mesma espacialidade podem ocorrer e conviver diferentes temporalidades e histórias. A resistência em aceitar tal possibilidade é que faz da fronteira um lugar de tensões, estranhamentos e conflitos.

Fronteira é, por conseguinte, o lugar em que os desencontros temporais e históricos se manifestam e se territorializam, mas isso só se dá porque é nesse lugar que o encontro entre os diferentes ocorre. Esse encontro é o contato, o qual pode reforçar o mútuo estranhamento historicamente construído, ao mesmo tempo em que possibilita a troca e o diálogo. O contato, portanto, é algo próprio da dinâmica espacial. Se dá de forma contingencial e de difícil controle e precisão, pois é bastante subversivo, corrompendo normas e poderes institucionalizados, construindo novas formas de comportamento e valores entre aqueles que estabelecem trocas, mas também pode ser violento e destruidor (Hissa, 2006).

Muitos antropólogos, sociólogos e pensadores dos estudos culturais (Bhabha, 2008; Canclini,1997; Hall, 2006; Figueiredo, 2005; Said, 1995) desenvolveram análises que visam expressar como povos e culturas que passaram por processos de dominação política e econômica criaram formas próprias de sobrevivência, levando a uma troca e influenciando os membros das classes e grupos dominantes. Assim, pode-se afirmar que ao criarem suas formas de sobrevivência, resistência e subversão em relação à ordem dominante, esses povos e culturas instauram uma espacialidade própria às condições de vida decorrentes.

Neste sentido, ao mesmo tempo em que a fronteira propicia o contato e a troca, é também inerente a ela revelar e colocar em contato a(s) diferença(s). Quando isso ocorre, instalam-se tensões que podem se configurar como limites para as possibilidades integrativas que a própria fronteira carrega.

Para Galeffi (2017: 23):

Sendo polissêmica, a fronteira é sempre um lugar marcado por signos de identidade e diferença, signos que apontam para o mesmo e para o outro, o 
"meu" e o do "outro". Como lugar, ocupa sempre espaço, seja ele geográfico, epistêmico, político e cultural. O espaço é, neste caso, uma dimensão da experiência dos corpos pertencentes ao mundo da vida.

Embora a discussão conceitual sobre fronteira aponte para seu caráter polissêmico e dinâmico, que não se restringe, nos dizeres de Raffestin (2005), ao sistema territorial, o imaginário construído a partir dos conteúdos geográficos trabalhados historicamente pela Geografia escolar tende a delinear a ideia de fronteira a partir das representações que os mapas estabelecem. A fronteira é uma linha, muitas vezes traçada sobre uma barreira de montanhas ou um rio, que delimita com precisão a divisão entre dois territórios. Essa forma generalizante de entendimento de divisão territorial simplifica a dinâmica dos processos espaciais, uniformizando sua complexidade em alguns elementos passíveis de controle e classificação.

Diante disso, indagamos: tal imaginário tem se perpetuado até os dias atuais? Como a Geografia escolar tem trabalhado a problemática da(s) fronteira(s)? Que papel teriam as imagens na construção desse imaginário?

\section{Por que as imagens?}

Neste trabalho priorizamos as imagens pois entendemos que sua presença e participação como potencializadoras de leituras e estabelecedoras de sentidos para os processos mais variados da vida cotidiana é indiscutível na atualidade. A intensificação das novas e sofisticadas tecnologias de comunicação e informação, assim como a forte presença dessas nos processos de criação e acesso a produtos pautados em referenciais cibernéticos, digitais e virtuais, conferiu às imagens papel importante no mundo contemporâneo. Os efeitos desse processo reverberam nos mais diversos níveis e estratos das relações sociais, assim como nos mecanismos de produção de conhecimento e nas instâncias em que o mesmo é trabalhado, como é o caso da educação escolar.

No campo acadêmico as pesquisas avançam nos estudos sobre a linguagem imagética. Tais estudos não se resumem ao tratamento das imagens como meras ilustrações; os pesquisadores têm buscando explorar as suas potencialidades e contribuições para pensar e compreender o mundo. Dentre muitos trabalhos sobre as linguagens imagéticas, percebemos uma corrente de autores que atribuem esta marcante presença das imagens como uma cultura visual, o que de acordo com Lima (2008) vem sendo utilizado para estudar e entender o mundo contemporâneo, que se encontra cada vez mais influenciado e construído pelas imagens.

Segundo Cazetta (2013: 12):

No contexto contemporâneo, as imagens têm participado dos mais distintos universos culturais, educando-nos e constituindo-nos como sujeitos (individuais e coletivos). A importância adquirida pelas imagens, sejam elas analógicas ou digitais, em fins do século XX e começo do XXI, pode ser entendida como parte de uma produção industrial da cultura mais generalizada, a qual nos autoriza dizer, juntamente com Miranda (2001) que há uma "educação do olho" em curso, cujas origens se situam no século XIX -momento em que o olhar passará a ser mediado por meio de aparelhos-. 
No âmbito da Geografia, desde fins do século XX tem se ampliado o volume de pesquisas e trabalhos envolvendo as muitas linguagens nas quais o conhecimento geográfico é produzido (Massey, 2008; Cosgrove e Daniels, 1988; Barnes e Gregory, 1997; Besse, 2006; Berque, 1998, entre outros). Tanto as imagens tradicionalmente utilizadas na Geografia -mapas, fotografias aéreas, imagens de satélite- como outras menos comuns nos trabalhos geográficos -desenhos, fotografias não panorâmicas, pinturas, cinema, televisão, imagens digitais e presentes na rede de computadores- passaram a ser objeto de estudo de profissionais e professores desse ramo do conhecimento.

Hollman e Lois (2015) apontam que embora a profissão do geógrafo tenha se constituído e legitimado em torno de práticas que possuem uma base no visual -na medida em que os geógrafos analisam, produzem, buscam e comparam imagens e as utilizam na produção, comunicação e no ensino do conhecimento geográficos- paradoxalmente, constata-se a ausência de uma reflexão sistemática sobre as imagens, seus modos de produção e utilização. Para as autoras:

En efecto, la historia de la disciplina muestra que solo recientemente se comenzó a reflexionar sobre su carácter visual y sobre el estatus asignado a las imágenes. Esta reorientación hacia la indagación de lo visual y de la visualidad no solo se ha dado en la geografía, sino que es una preocupación compartida por diversas disciplinas del campo de las ciencias sociales, movimiento que ha sido denominado genéricamente "giro visual" [visual turn]. También llamado pictorial turn (Mitchell, 1989) o iconic turn (Moxey, 2008), implica el reconocimiento de que las imágenes constituyen un orden de conocimiento específico, íntimamente relacionado con las palabras, aunque no pueda ser equiparado con ellas. En otro orden, el giro visual cuestiona la existencia de un modo universal de ver/mirar las imágenes (2015: 29).

Diante da constatação da escassa problematização das imagens, Hollman buscou analisar a Geografia escolar como um discurso visual sobre o mundo e sua participação na formação de um sentido e uma cultura comuns. Para isso, tomou como objeto de análise as imagens presentes em livros escolares de Geografia produzidos em três períodos históricos que constituem momentos chave na história da cultura visual na Argentina.

Para Hollman (2014: 222-223):

Não surpreende o marcado conteúdo visual dos livros didáticos de geografia (Hollman, 2010; 2013a) se pensarmos na sua tradição visual e sua orientação à instrução visual (Rose, 2003; Cosgrove, 2008). Além do seu valor didático, geralmente reconhecido na disciplina e sua didática, as imagens que circulam nos livros didáticos documentam, expõem, fazem seleções, ordenam e sistematizam informações. Ainda mais: as imagens presentes nos livros didáticos -assim como em outros registros discursivos- participam ativamente em nossas maneiras de classificar, entender e nos posicionar no mundo. Sabemos, porém, que as imagens não são espelhos da realidade senão regimes visuais que constroem o nosso olhar. Então, os livros escolares não apresentam a realidade, mas regimes visuais do real. 
No entendimento da autora, portanto, a Geografia escolar é um discurso visual do mundo, ativamente envolvido na criação de um sentido geográfico e passível de ser estudado através dos livros didáticos -entre outros registros e materiais-.

Com base neste entendimento, nossa investigação voltou-se à identificação das imagens presentes nos livros didáticos de Geografia utilizados no Brasil e na Argentina ${ }^{3}$ quando estes abordam assuntos/conteúdos relativos à fronteira. Neste movimento, verificamos o predomínio de imagens fotográficas, embora também compareçam mapas e esquemas, entre outras, mas em número bastante inferior às fotografias. ${ }^{4}$ Diante disso, optamos em desenvolver nossa análise apenas sobre as fotografias presentes nesses materiais, considerando que as fotografias fazem parte de um discurso mais amplo que as contém e lhes dá sentido.

Sobre as imagens fotográficas, cabe ressaltar que, em geral, são concebidas como uma representação de algo realmente existente, sendo aceitas e utilizadas como "prova definitiva, testemunho da verdade do fato ou dos fatos" conforme aponta Kossoy (2002: 19), "graças a sua natureza fisicoquímica e hoje eletrônica de registrar aspectos (selecionados) do real, tal como estes fatos se parecem, a fotografia ganhou elevado status de credibilidade". Para Tagg (1988: 11), não é somente o elemento material que confere realidade à fotografia, mas também todo o sistema discursivo no qual a imagem está contida. Assim, "No es hacia la realidad del pasado, sino de los significados presentes y de los sistemas discursivos cambiantes hacia donde debemos, por tanto, volver nuestra atención".

Ainda neste sentido, Dubois (2015: 36) afirma que a foto não é apenas uma imagem produto de uma técnica e uma ação. Para este autor, em primeiro lugar, é um ato icônico, mas em trabalho: “(...) por lo tanto, algo que es a la vez y consubstancialmente una imagen-acto, habida cuenta de que este 'acto', trivialmente, no se limita al solo gesto de la producción propiamente dicha de la imagen (el gesto de la 'toma') sino que además incluye el acto de su recepción y de su contemplación".

As ideias e questões trazidas por esses autores nos permitem pensar dois aspectos importantes: as fotografias nos livros didáticos constituem parte de um sistema discursivo; como o ato fotográfico não se encerra na sua produção, a presença das fotografias nos livros didáticos deve ser considerada também no que se refere à sua recepção e contemplação em um lugar específico que é a escola.

Hollman e Lois (2015: 104) ao discutirem o caráter documental da fotografia, afirmam que este se deve não somente à natureza mecânica do ato fotográfico, mas também ao

3 No caso do Brasil, analisamos todas as coleções de livros didáticos aprovados no Programa Nacional do Livro Didático (PNLD)/2017, por entendermos que essas são as mais utilizadas nas escolas brasileiras em vista da sua distribuição gratuita a toda rede pública do país. As coleções podem ser identificadas em: http://www.fnde. gov.br/programas/programas-do-livro/livro-didatico/guia-do-livro-didatico/item/8813-guia-pnld-2017. No caso da Argentina, analisamos as edições mais recentes (2015, em sua maioria) disponibilizadas para venda pelas editoras, já que naquele país não há uma política de avaliação e distribuição gratuita de livros didáticos similar ao PNLD - as coleções estão elencadas na bibliografia deste artigo-. É também importante salientar que os livros didáticos brasileiros analisados se referem ao Ensino Fundamental ( $6^{\circ}$ ao $9^{\circ}$ ano) já os argentinos foram do nível médio, pois na estrutura curricular da educação básica argentina, a disciplina de Geografia comparece apenas nesse nível de ensino.

4 Em levantamento realizado por Oliveira Junior e Soares (2012) constatou-se que cerca de metade das imagens presentes nos livros didáticos são fotografias, superando inclusive o número de mapas. 
fato de que esse ato foi exercido por alguém que ali esteve, portanto, não apenas certificou a existência da situação registrada, como também foi testemunha do acontecimento: "Así, la foto se impone como el registro que documenta el acto mismo de testimoniar".

As referidas autoras também assinalam que no momento atual observa-se a hegemonia do fotoperiodismo no discurso da Geografia escolar, sobretudo nos livros escolares: "El discurso geográfico escolar introduce el fotoperiodismo con la finalidad de documentar los eventos actuales, y así también promueve un modo de mirar el mundo" (Hollman e Lois, 2015: 182). Esse modo de mirar o mundo coloca a fotografia como um documento que prova a veracidade da informação do texto, atribuindo maior legitimidade ao texto informativo.

Assim como destacado pelas autoras, também constatamos que a maior parte das imagens fotográficas publicadas nos livros didáticos brasileiros e argentinos tem como origem arquivos visuais de empresas periodística. ${ }^{5}$ Quando inseridas nos livros didáticos de Geografia, as fotografias aparecem como evidências daquilo que nos trazem à vista e funcionam quase que exclusivamente como provas ou exemplos do que se afirma no texto escrito que antecede, sucede ou legenda. "Desta forma, podemos dizer que as fotos auxiliam no processo de memorização, permitindo que, no futuro, os estudantes relembrem da 'matéria' a partir da lembrança da fotografia" (Oliveira Junior e Soares, 2012: 114-115).

Relembrar a matéria a partir da lembrança da fotografia -isso significaria dizer que as informações e compreensões sobre os assuntos/conteúdos, de alguma maneira, estariam presentes resumidamente nas fotografias que acompanham os textos nos livros didáticos-. Então, poderíamos deduzir que as fotografias contribuem significativamente para construir determinadas ideias e concepções sobre fronteira. Quais seriam essas concepções?

\section{0 que dizem as imagens?}

Antes de apresentarmos as imagens fotográficas encontradas na pesquisa realizada, fazse importante explicitar em quais conteúdos ou assuntos tratados pelos livros didáticos de Geografia geralmente é abordada ou mencionada a fronteira e, por conseguinte, estão presentes essas imagens.

Tanto nos livros didáticos de Geografia brasileiros, quanto nos argentinos, os conteúdos ou assuntos em que a ideia de fronteira comparece são: população (processos migratórios internacionais); México no contexto da América Latina; África (fronteiras políticas e étnicas); Limites e fronteiras do Brasil ou da Argentina (territórios nacionais e soberania); Nações e estados (Curdistão); integração regional na América Latina; guerras e conflitos territoriais ou fronteiriços no mundo; Europa (entrada de imigrantes); América do Sul (Tríplice Fronteira, geoeconomia e geopolítica); América Anglo-Saxônica; contradições da globalização; América latina (política e território).

5 Aqui se faz importante destacar que nos livros didáticos argentinos não comparecem as informações sobre autoria das fotos e a identificação clara sobre a fonte ou acervo de origem. Ao contrário, nos livros didáticos brasileiros essas informações são obrigatórias, na medida em que este é um elemento observado na avaliação realizada pelo PNLD. 
FLAVIANA GASPAROTTI NUNES

Nas Figuras 1 a 6 temos algumas das imagens fotográficas mais recorrentes nos livros didáticos de Geografia, nos capítulos que abordam assuntos em que a ideia de fronteira comparece. As fotografias de muros ou grades existentes em diversos lugares do mundo (com destaque para as da fronteira entre México e Estados Unidos que comparecem em maior número) são bastante utilizadas para ilustrar essa questão.

A foto da Figura 1 acompanha um texto do capítulo referente aos aspectos econômicos do México, citando os Estados Unidos como principal parceiro comercial; menciona os acordos comerciais existentes, mas destaca que esses não incluem a livre circulação de pessoas. Embora os muros não sejam mencionados diretamente no texto principal, a legenda que acompanha a foto traz a ideia de que a construção de muros e grades na fronteira tem o objetivo de conter a entrada ilegal de imigrantes nos Estados Unidos. Da mesma forma, a foto da Figura 2 embora esteja presente em um texto que aborda o contexto mundial atual onde há livre circulação de mercadorias, mas não de pessoas, o muro que separa o México dos Estados Unidos é utilizado como um exemplo desta situação. Enquanto que a Figura 3 acompanha um texto que trata especificamente da lei estadunidense que restringe a entrada de imigrantes. Assim, seu sentido de comprovação da realidade, ou seja, de veracidade das informações contidas no texto fica bastante evidenciado.

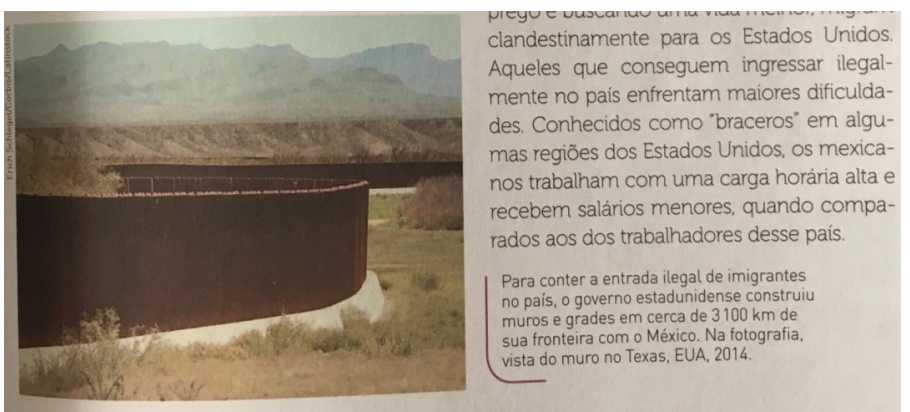

Figura 1. Muro no Texas, EUA, 2014. Fonte: Magalhães, 2015: 115.

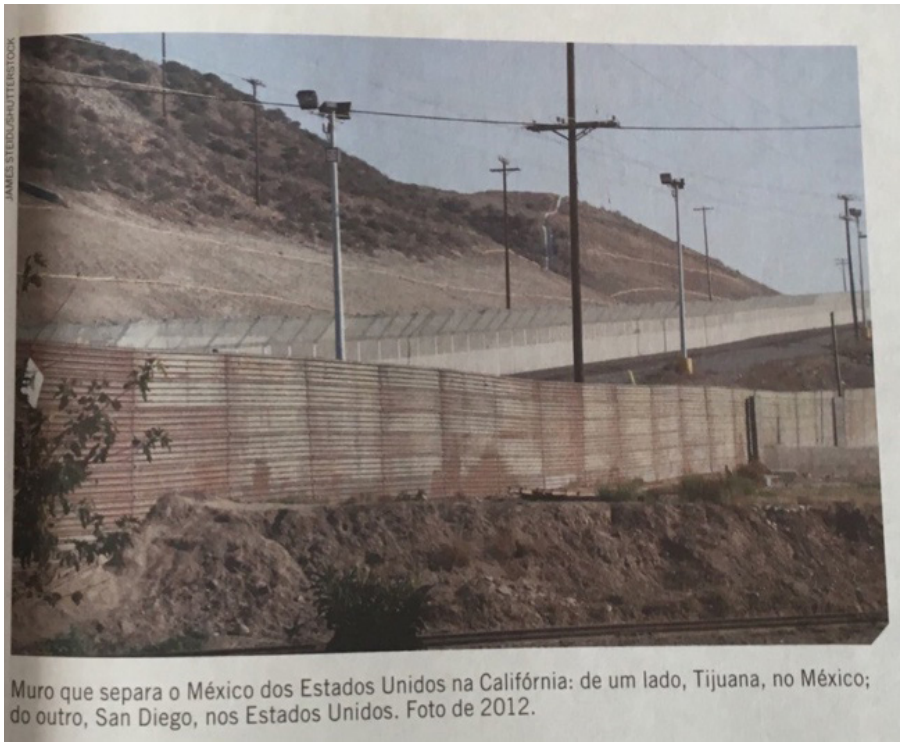

Figura 2. Muro México/EUA. Fonte: Garcia e Moraes, 2015: 79. 


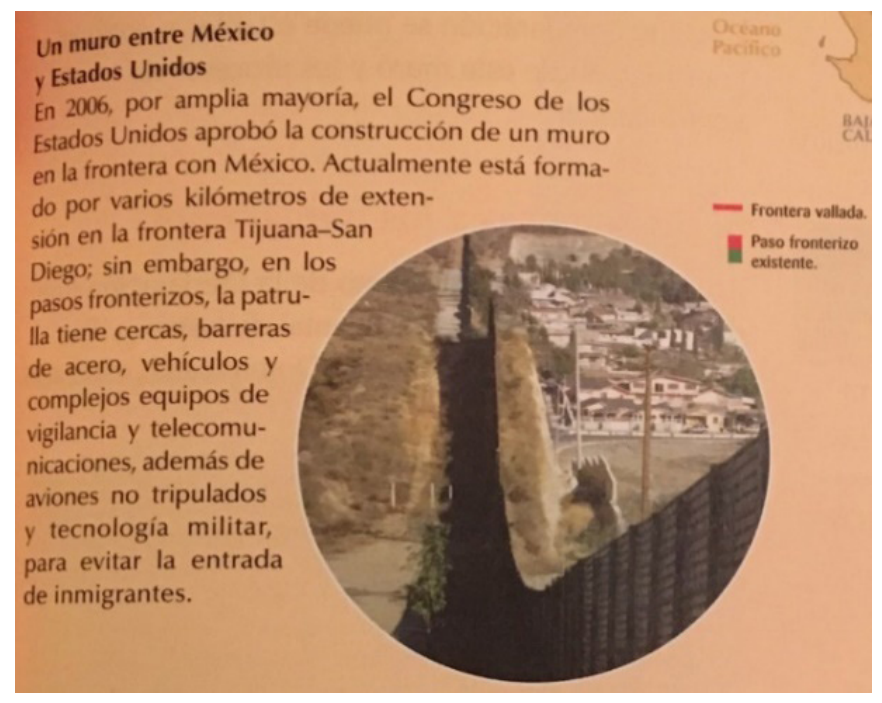

Figura 3. Muro México e Estados Unidos. Fonte: Zapepettini, 2015: 157.

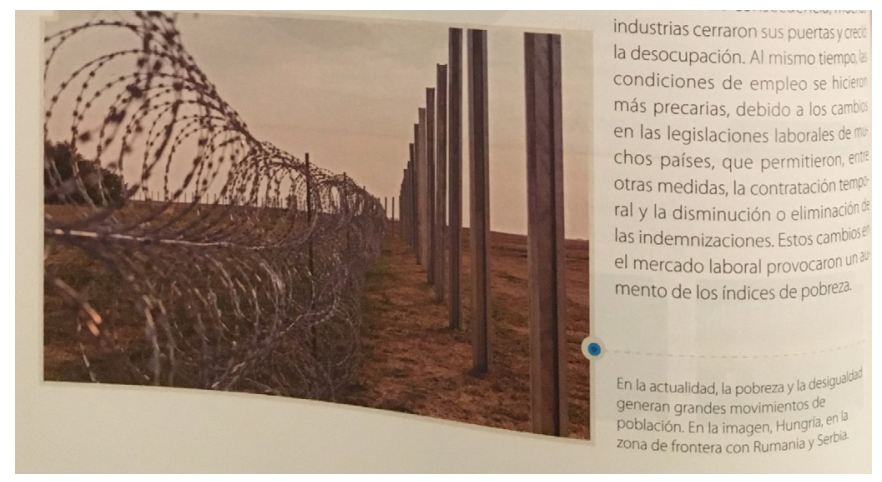

Figura 4. Frontera Hungria con Rumania e Serbia. Fonte: Dautério et al., 2016: 86.

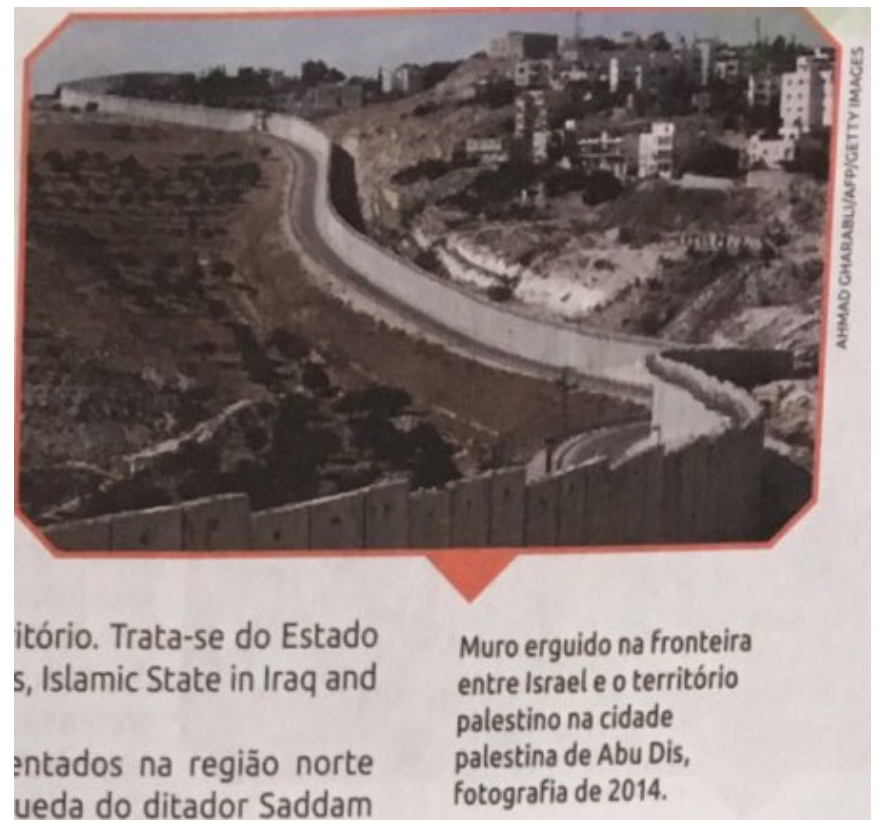

Figura 5. Muro na fronteira Israel e Palestina. Fonte: Furquim Jr, 2015: 19. 


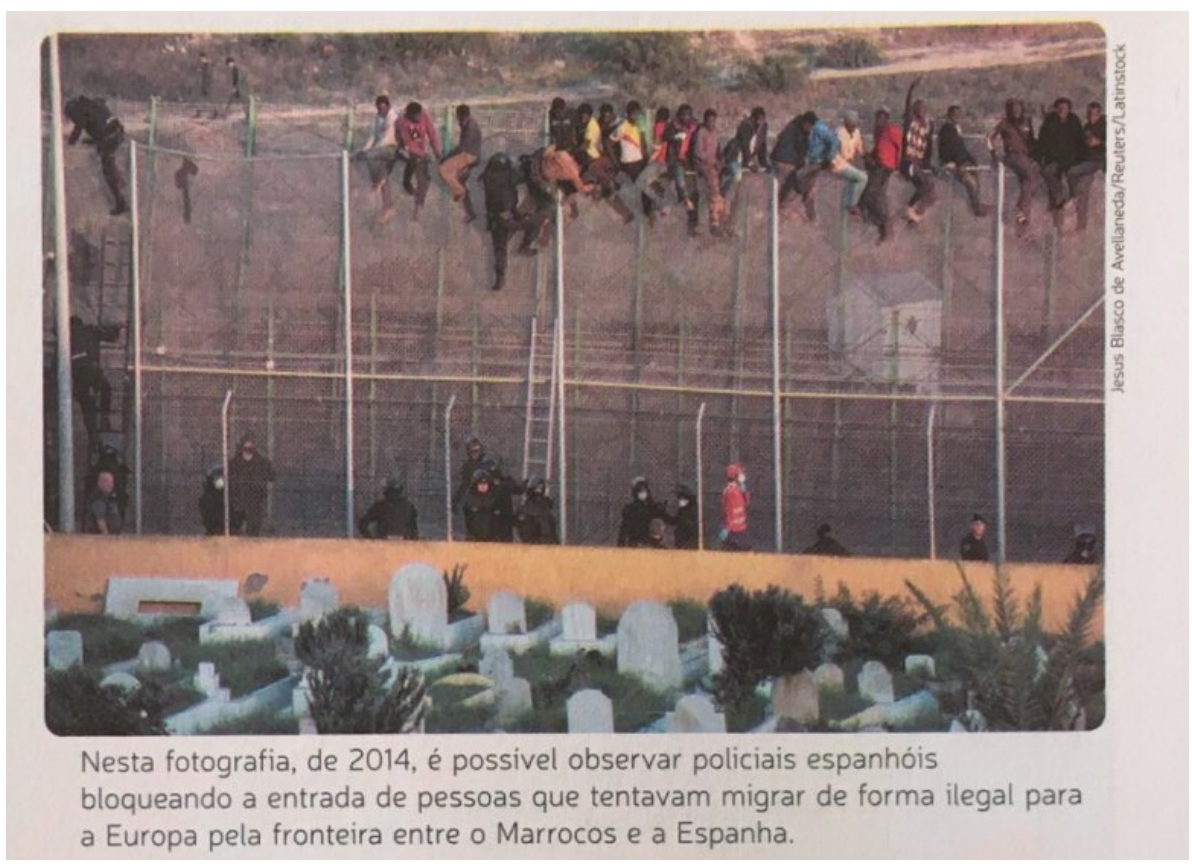

Figura 6. Fronteira Marrocos e Espanha. Fonte: Torrezani, 2015: 13.

Embora as fotografias das Figuras 1 a 3 destaquem o muro entre Estados Unidos e México, a da Figura 5 destaque o muro na fronteira entre Israel e Palestina, e as das Figuras 4 e 6 as cercas na fronteira da Hungria com a Romênia e Sérvia e entre Marrocos e Espanha, o sentido construído por todas essas imagens aproxima-se à ideia de fronteira como limite, barreira e contenção.

A foto da Figura 6 é uma das poucas em que junto aos muros aparecem pessoas: de um lado, migrantes africanos e, de outro, policiais espanhóis que são identificados pelos uniformes e armas. O texto refere-se à fotografia da seguinte forma: “(...) a imagem acima apresenta um dos problemas enfrentados pela Europa nas últimas décadas: a imigração ilegal de pessoas de diversas origens, especialmente da África, do Oriente Médio e do Leste Europeu" (Torrezani, 2015: 13). Ao tratar a questão imigratória como um problema, a utilização da fotografia também conduz ao entendimento de que as causas do mesmo estariam relacionadas às pessoas que pulam as cercas e atravessam as fronteiras.

Outra imagem fotográfica presente nos livros didáticos brasileiros e argentinos é aquela em que agentes estatais (polícia ou exército) aparecem realizando operações ou ações que visam garantir a segurança e o controle das fronteiras nacionais (Figuras 7 a 10). Nessas fotografias a presença do Estado é evidenciada por elementos como os uniformes dos agentes federais ou policiais, e as cenas em que esses agentes aparecem são aquelas em que estão em serviço, controlando e fiscalizando a entrada e saída de pessoas (na maioria das vezes) e mercadorias. 


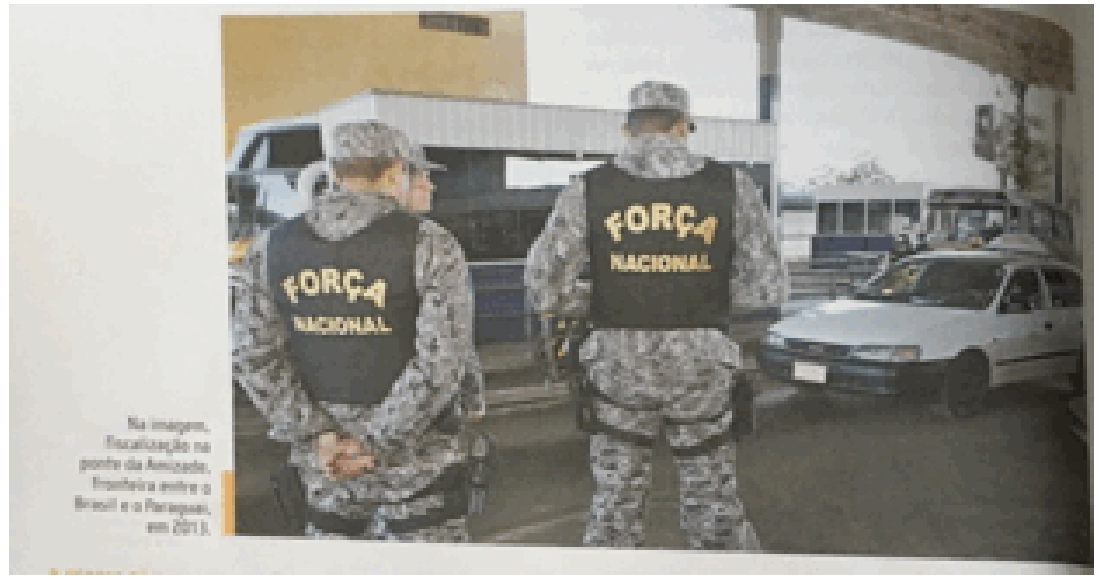

Figura 7. Fiscalização na ponte da Amizade. Fonte: Garcia e Belluci, 2015: 50.

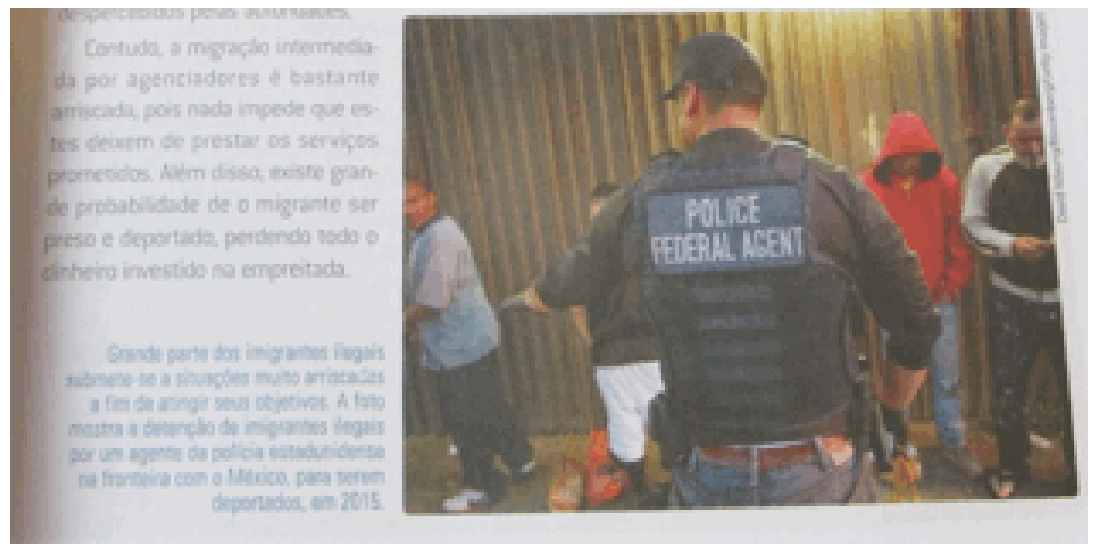

Figura 8. Detenção de imigrantes na fronteira México/EUA. Fonte: Alves, 2015: 35.

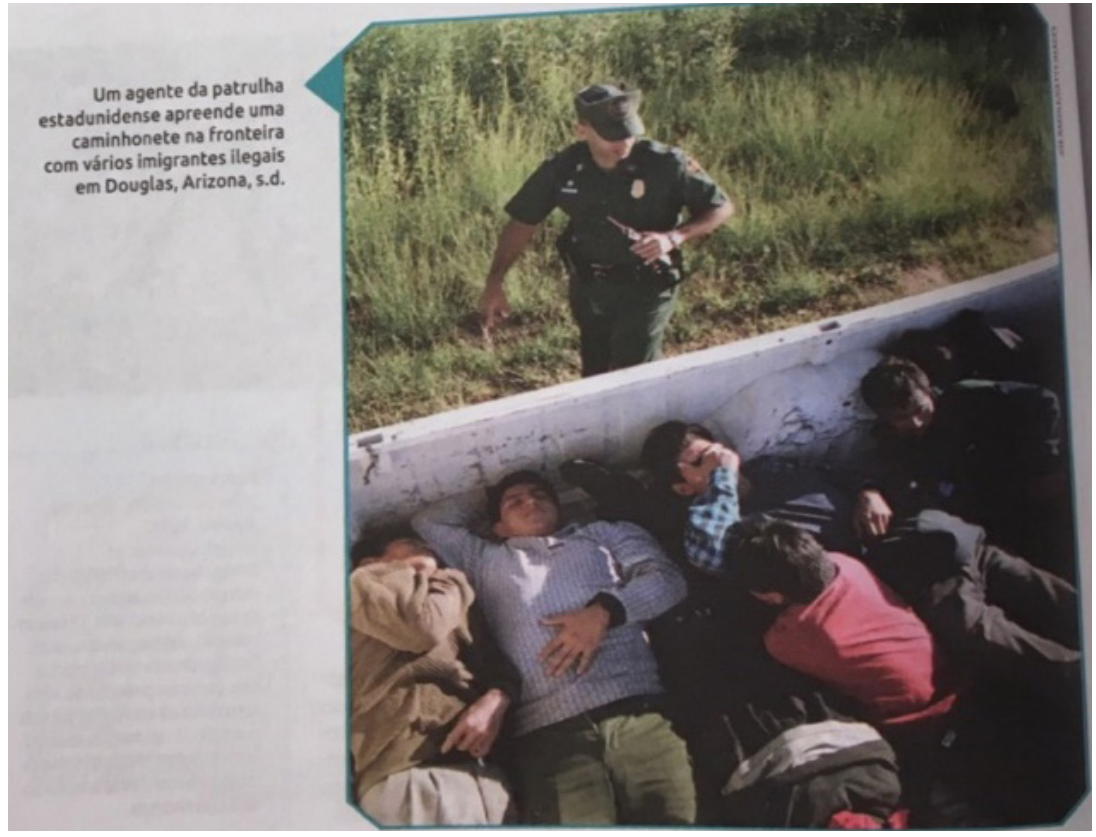

Figura 9. Agente de patrulha estadunidense apreende migrantes ilegais no Arizona. Fonte: Furquim Jr, 2015: 114. 


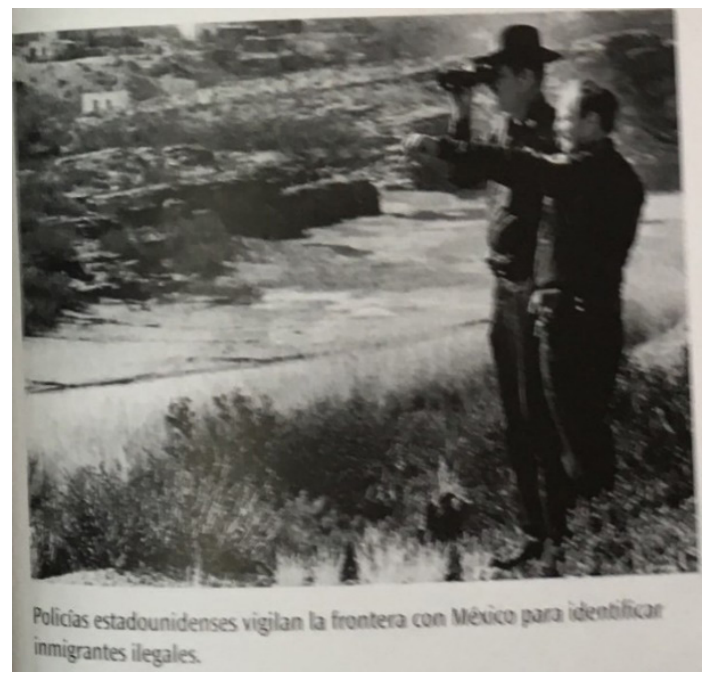

Figura 10. Policiais estadunidenses vigiam fronteira. Fonte: Ataíde, 2015: 223

Também associadas ao controle das fronteiras, identificamos fotografias que trazem em destaque outros elementos (além dos agentes estatais) os quais se configuram como instrumentos legais necessários para ultrapassar as fronteiras nacionais. Na Figura 12, por exemplo, o passaporte com diversos carimbos como foco central da fotografia contribui para reforçar a ideia de fronteira como limite que só pode ser ultrapassado se houver atendimento às normas e se $\mathrm{o}$ indivíduo estiver adequado às determinações legais, ou seja, legalmente documentado. A foto da Figura 11, por sua vez, remete às consequências do não atendimento às normas impostas pelo Estado nação de destino. Serve como comprovação de que a ilegalidade é punida pelos agentes estatais, o que também reafirma a ideia de fronteira como limite ou barreira de difícil transposição: burocratizada, vigiada e repressiva.

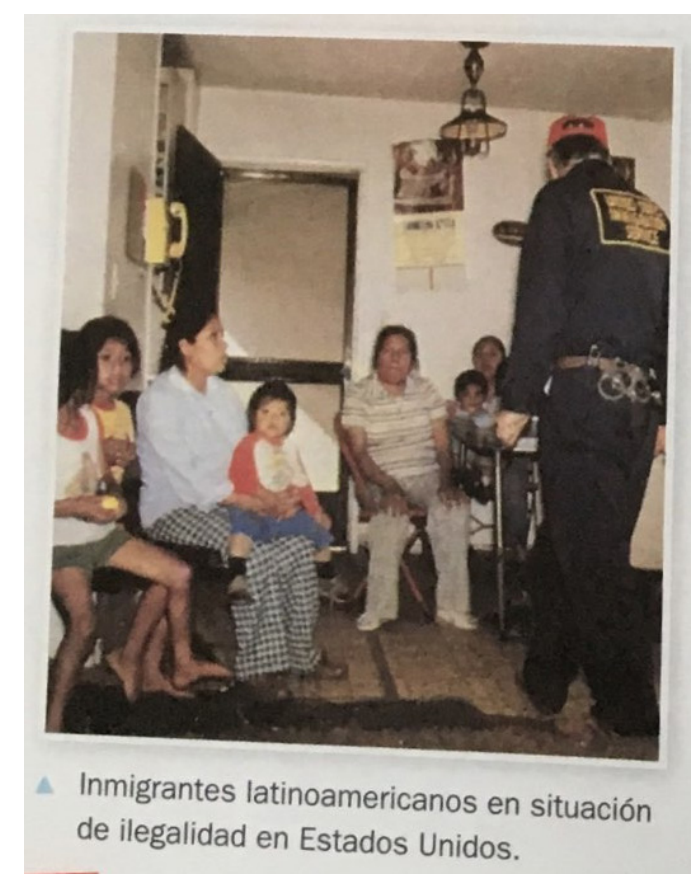

Figura 11. Imigrantes ilegais nos EUA. Fonte: Bustos, 2015: 56. 


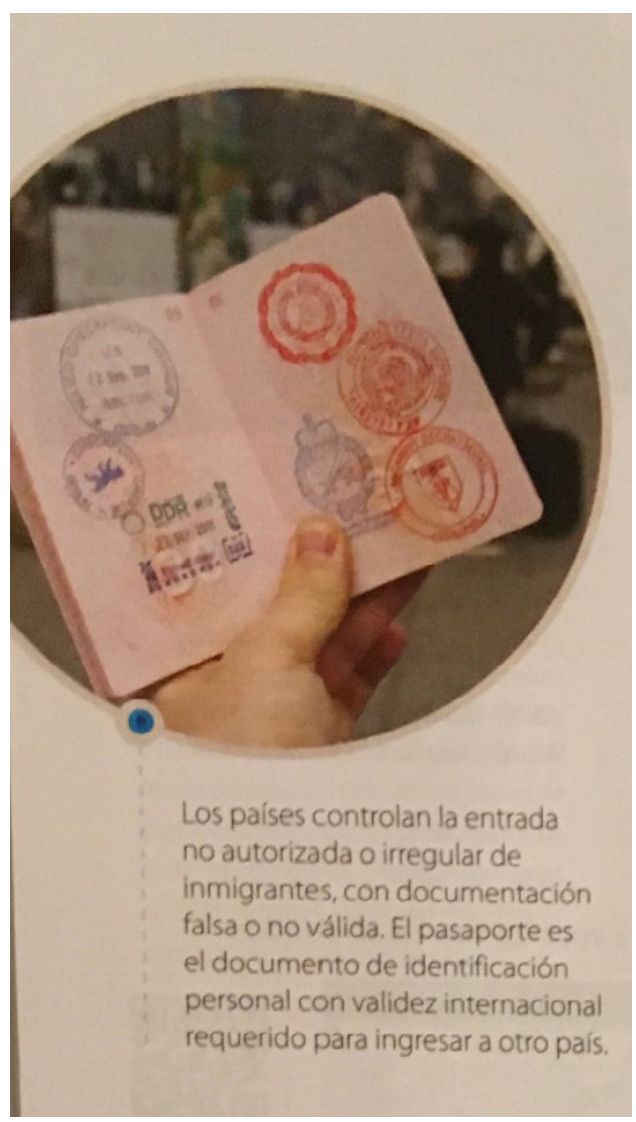

Figura 12. Passaporte. Fonte: Bembi, 2016: 152.

Por outro lado, as fotografias nas quais são destacadas pontes, estradas ou vias de acesso (Figuras 13 a 16) conferem uma conotação mais positiva à fronteira, na medida em que trazem as possibilidades do contato entre dois ou mais lados. Nessas fotografias, geralmente aparecem em destaque as placas de boas-vindas para aqueles que chegam ao país, além do trânsito de veículos e pessoas, o que possibilita pensar a fronteira como contato, intercâmbios ou mesmo integração entre dois ou mais países.

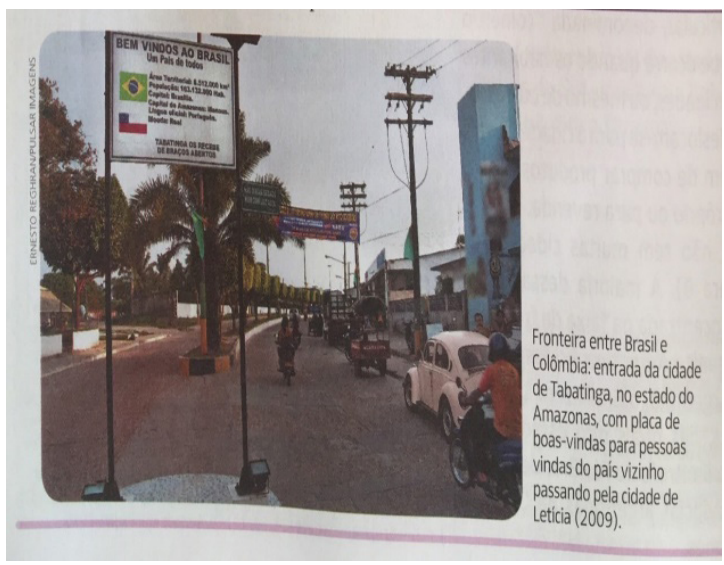

Figura 13. Fronteira Brasil/Colômbia. Fonte: Adas e Adas, 2015: 282. 


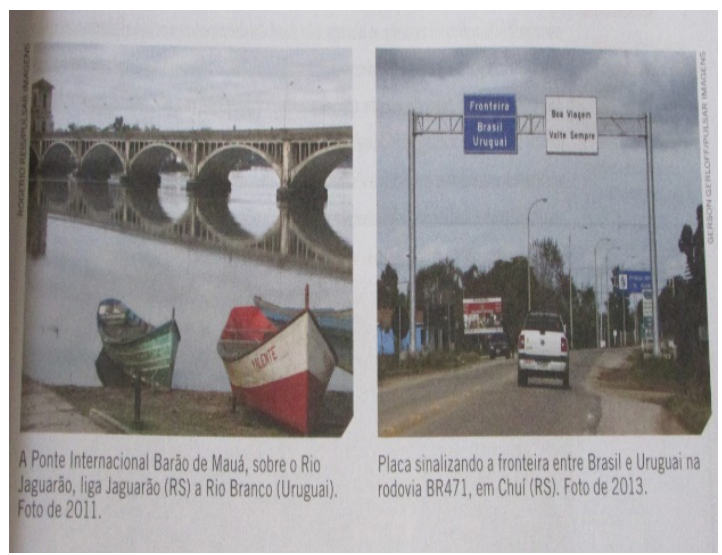

Figura 14. Pontos da Fronteira Brasil/Uruguai. Fonte: Garcia e Moraes, 2015: 17.

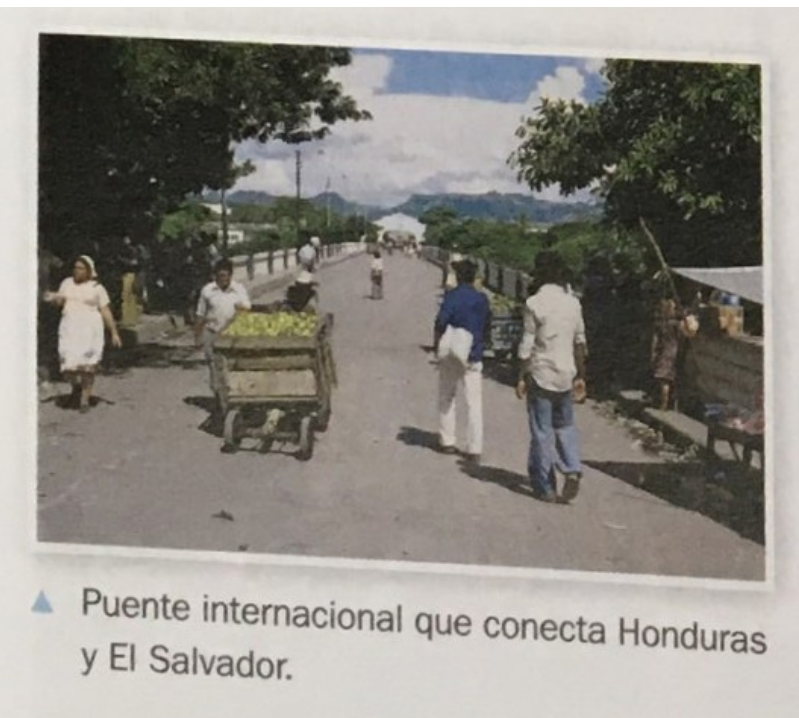

Figura 15. Ponte Honduras/El Salvador. Fonte: Bustos et al., 2015: 204.

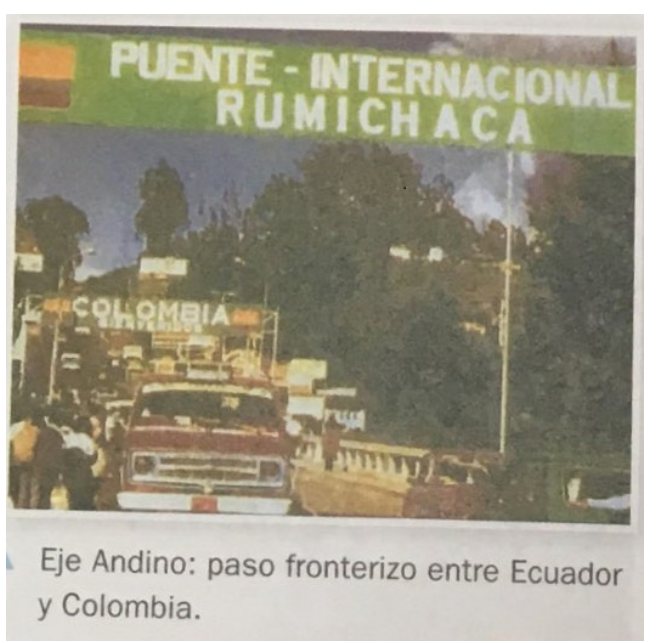

Figura 16. Fronteira Equador/Colômbia. Fonte: Bustos et al., 2015: 206. 
FLAVIANA GASPAROTTI NUNES

A explicitação da demarcação de limites precisos entre um lado e outro da fronteira, ou seja, a identificação clara sobre onde é o fim de um território e início de outro, é um aspecto bastante salientado nas fotografias presentes nos livros didáticos (Figuras $17 \mathrm{e}$ 18). Neste caso, é interessante observar que o mesmo elemento fotografado -o monólito, por exemplo- a depender da legenda que acompanha a foto, pode adquirir sentidos/ significados distintos: se na foto da Figura 17 destaca-se a ideia do monólito como um demarcador de limite, na foto da Figura 18 esse mesmo elemento é entendido como um símbolo de integração entre três Estados nacionais.

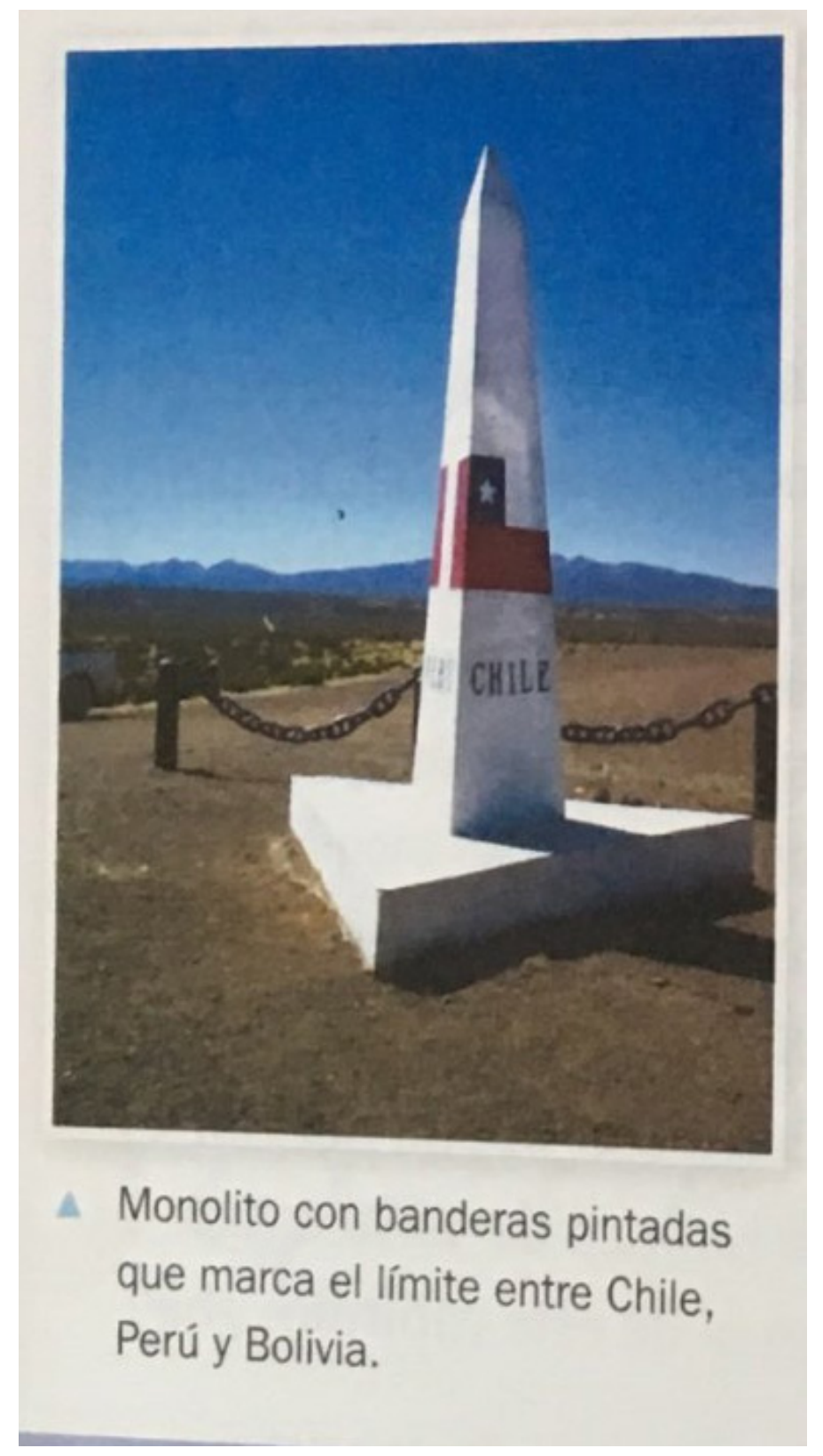

Figura 17. Monolito limite entre Chile, Peru e Bolívia. Fonte: Bustos et al., 2015: 222 


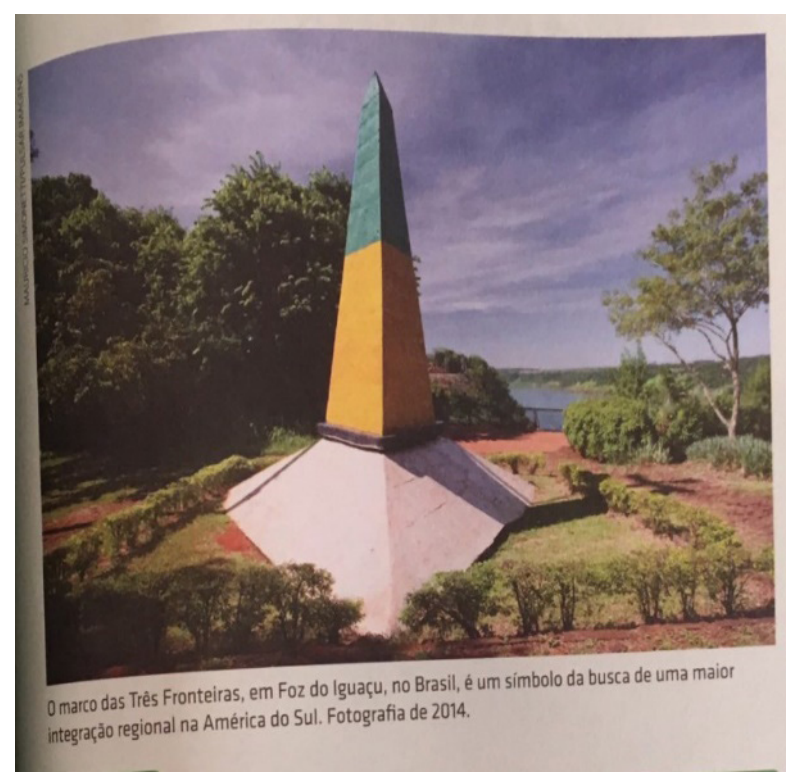

Figura 18. Marco das Três Fronteiras. Fonte: Ribeiro, 2015: 169.

A demarcação precisa do início e fim dos territórios nacionais também é feita por meio de fotografias em que são destacados os símbolos nacionais, sobretudo bandeiras (Figuras 19 e 20). As bandeiras conferem a ideia de identidade nacional -delimitação territorial e identificação a partir de símbolos constroem uma identidade e, por consequência, a distinção em relação ao outro-.

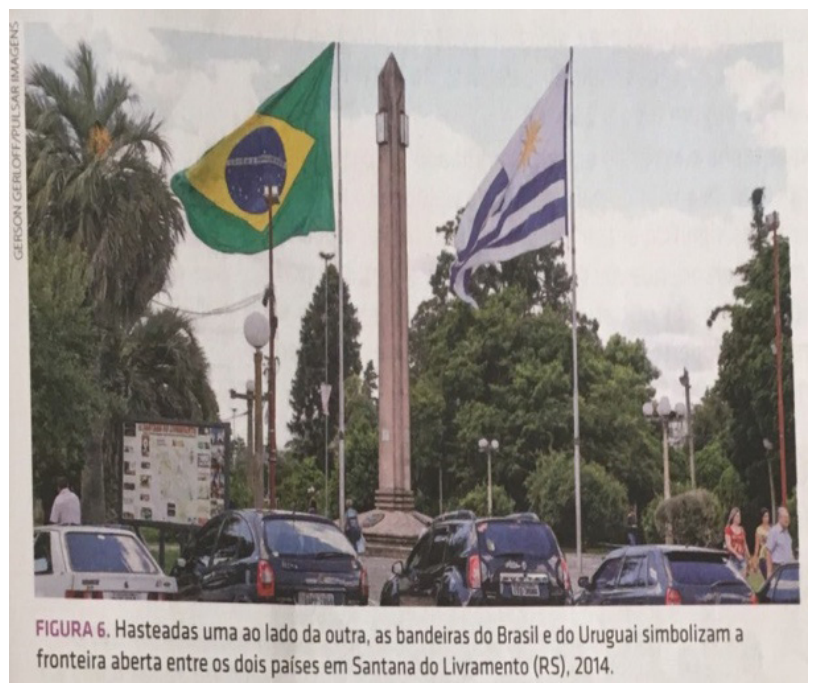

Figura 19. Fronteira Brasil/Uruguai em Santana do Livramento (RS). Fonte: Ribeiro, 2015: 268. 


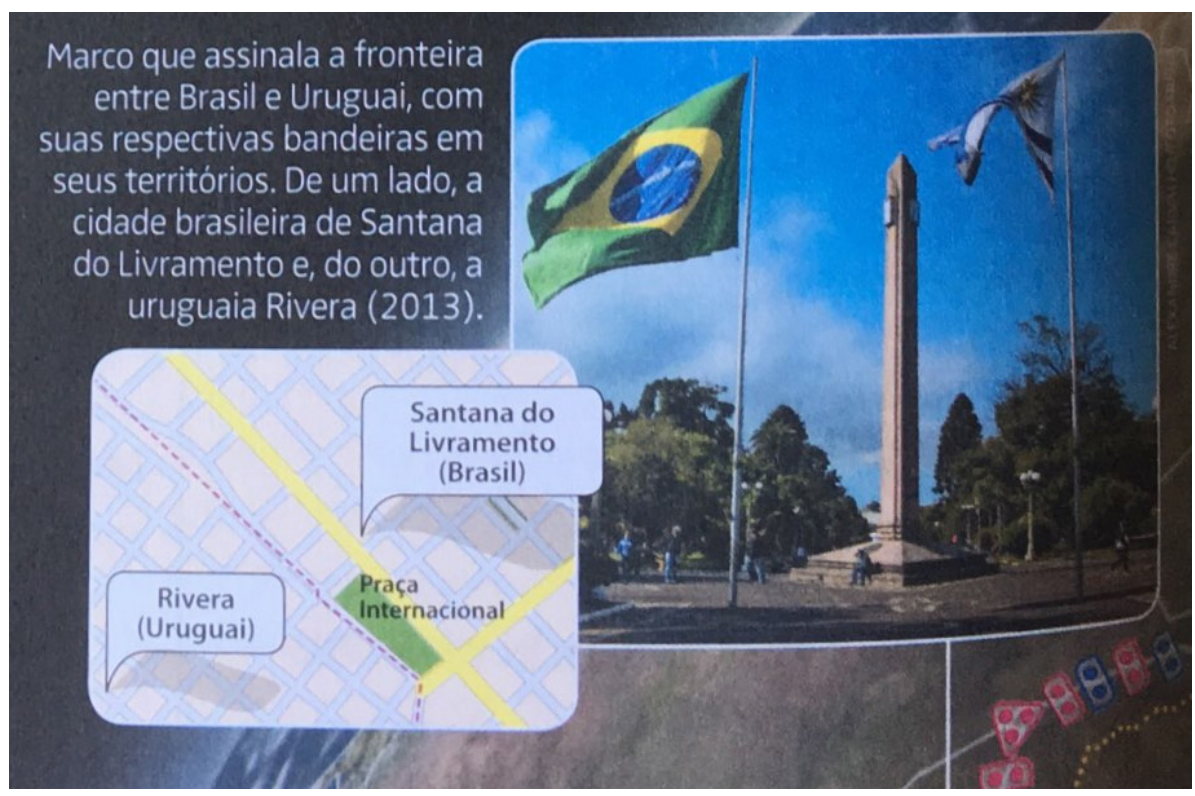

Figura 20. Fronteira Brasil/Uruguai em Santana do Livramento (RS). Fonte: Adas e Adas, 2015: 268.

Em vista das imagens identificadas nos livros didáticos de Geografia brasileiros e argentinos, constatamos que nesses materiais prevalece a ideia de fronteira como limite, barreira, separação de lados, bastante associado ao caráter estatal, burocrático e controlador da mobilidade das pessoas.

Ao realizarmos uma busca no Google Imagens utilizando apenas a palavra fronteira ou fronteiras, ${ }^{6}$ e as imagens resultantes da pesquisa são muito parecidas com aqueles presentes nos livros didáticos. Desta forma, questionamos: em que medida os livros didáticos de Geografia, e consequentemente a Geografia escolar, estariam ampliando ou reproduzindo um mesmo imaginário sobre a fronteira já construído a partir do olhar midiático?

Compartilhamos, neste sentido, do incômodo de Oliveira Junior e Soares (2012: 128):

Nosso incômodo em relação a estas imagens fortemente documentais e figurativas é que no mundo contemporâneo estas ilustrações, comunicações, explicações e informações visuais estão facilmente disponíveis nas plataformas virtuais da internet, sendo, portanto, relativamente desnecessárias nos materiais didáticos. Nos perguntamos então: não seria o caso de inventarmos imagens que tivessem mais potência nos ambientes educativos para levar os alunos a pensarem acerca destes assuntos ou lugares ao invés de somente se informarem visualmente sobre eles?

No caso da fronteira, não existiriam outras imagens com potência para nos fazerem pensá-la para além do "fato geográfico que ela realmente é, pois ela não é só isso", conforme já nos alertou Raffestin (2005: 10)?

6 Realizamos a busca no Google Brasil e no Google Argentina e os resultados pouco diferiram. A principal diferença encontrada refere-se às imagens específicas das fronteiras de cada um dos países. 


\section{Considerações finais}

Encerramos este texto com mais indagações do que necessariamente conclusões. Entre as conclusões, podemos apontar que, a partir da pesquisa realizada nos livros didáticos de Geografia brasileiros e argentinos, predominam imagens fotográficas que reforçam e restringem a ideia de fronteira como fixação de limites territoriais estatais estabelecidos por meio de barreiras físicas ou controles burocráticos, sobretudo para a mobilidade das pessoas.

Se no campo conceitual amplia-se a discussão sobre os sentidos de fronteira, no campo escolar isso não tem ocorrido. Mesmo nos textos didáticos que intencionam trazer uma compreensão mais ampla de fronteira no sentido dos contatos e integração, as imagens utilizadas são vias de acesso (estradas e pontes) nas quais está mais presente o aspecto comercial do que de intercâmbios culturais por exemplo, o que não associa fronteira à questão de identidades e diferenças. Também podemos afirmar que a maior parte das fotos tem a função de comprovar alguma informação do texto; raramente as fotos são utilizadas para problematizar a ideia de fronteira.

Considerando que nesses materiais predominam imagens fotográficas periodísticas provenientes de bancos e arquivos de grandes agências de notícias, questionamos: E se, nas aulas de Geografia, fossem utilizados outros tipos de fotografias, como as artísticas, por exemplo?7 ${ }^{7}$ Seria possível construir outros sentidos de fronteira?

Pensamos que é possível responder afirmativamente a esta questão. Quando realizamos a busca no Google Imagens a partir da palavra fronteira, além das imagens recorrentes que também estão presentes nos livros didáticos de Geografia (muros, grades, cercas, bandeiras, marcos simbólicos, pontes, agentes estatais, etc.), tomamos contato com outras imagens (em menor número) que tensionam ou rasuram os sentidos hegemônicos construídos por essas imagens. Citamos, a título de exemplificação, duas dessas imagens: a de um jogo de voleibol e a de um menino que brinca com os muros da fronteira entre México e Estados Unidos. ${ }^{8}$

Na imagem do jogo de voleibol ocorrido entre as cidades fronteiriças de Naco (Arizona, Estados Unidos) e Naco (Sonora, México), o muro transforma-se em rede e os territórios nacionais separados por uma fronteira/muro podem ser pensados apenas como dois lados de uma mesma quadra de jogo. A quadra de jogo seria uma analogia ao território no qual pode haver mudança de lados ao término de cada set da partida? Essa mudança de lados poderia ser pensada como colocar-se no lugar do outro?

Na segunda imagem vemos um menino brincar com os muros da fronteira entre México e Estados Unidos, no trabalho do artista francês JR instalado em outubro de 2017 na cidade mexicana de Tecate, a sudeste de San Diego. Trata-se de uma fotografia monumental de Kikito, uma criança mexicana, sorridente de um ano de idade, colada em

7 Neste caso não nos referimos somente ao livro didático, pois temos conhecimento de que uma das maiores dificuldades para a inclusão de fotografias artísticas nesses materiais é o custo dos direitos autorais que, na maior parte dos casos, é muito superior ao das fotografias provenientes de bancos de agências.

$8 \mathrm{~A}$ imagem do jogo de voleibol pode ser encontrada em diversos sites (entre eles http://www.jornalciencia.com/ top-20-fronteiras-mais-incriveis-do-mundo/) e a do menino refere-se a uma instalação feita pelo artista francês JR (http://www.jr-art.net) 
FLAVIANA GASPAROTTI NUNES

um andaime especial colocado logo atrás da cerca da fronteira com a Califórnia. Na instalação, melhor vista do lado norte americano, a criança parece estar examinando a cerca de lâminas como se estivesse dentro de um berço, preparando-se para rastejar em direção a algo que atraiu seu interesse. Ao colocar uma criança brincando alegremente com a cerca que delimita a fronteira como se esta fosse seu próprio berço (que remete ao sentido de acolhimento e proteção), JR nos provoca a pensar que, talvez, para aquela criança o sentido desta cerca pode ser exatamente o contrário daquele instituído pelos Estados Unidos.

O que mais essas imagens nos dariam a pensar? Esboçamos aqui apenas algumas ideias que demostram as possibilidades de ampliação e construção de outros sentidos de fronteira que essas imagens auxiliariam a construir, em contraponto àquelas predominantes nos livros didáticos de Geografia comumente utilizados nas escolas brasileiras e argentinas.

Agradecemos ao Programa de Apoio à Pós-Graduação (Chamada FUNDECT/CAPES $n^{\circ}$ 44/2014 - PAPOS-MS) pelo financiamento parcial do estágio de pós-doutorado. 


\section{Q Bibliografia}

" Albuquerque, J. L. (2010). A dinâmica das fronteiras: os brasiguaios na fronteira entre o Brasil e o Paraguai. São Paulo: Annablume.

» Arzeno, M.,Balbiano, A. J., Casaubón, H. J. , Echeandia, D. L. de, García, P. A., Grimau, J. A., Martin, F. E., Migale, G. M., Minvielle, S. E., San Cristóbal, D. H., Snyrynskyj, G. C. e Troncoso, C. A. (2015). Geografía: Espacios geográficos de la Argentina. Ciudad Autónoma da Buenos Aires: Santillana.

" Ataíde, S., Bertoncello, R., Casaubón, H., García, P.A., Marcos, M. F., Minvielle, S. E., Snyrynsyj, G. C. e Soto, M. (2015). Geografía: el mundo y la globalización. Ciudad Autónoma de Buenos Aires: Santillana.

» Barnes, T. e Gregory. D. (1997). Reading Human Geography - the poetics and politcs of inquiry. Londres: Arnold.

» Bembi, M., Daltério, L., Freiman D. R. e Rovatti, D. (2016). Avanza: geografía, ambientes y población en el mundo. Ciudad Autónoma de Buenos Aires: Kapelusz.

"Berque, A. (1998). Paisagem-Marca, Paisagem-Matriz: elementos da problemática para uma geografia cultural. En: R. L. Correa e Z. Rosendahl, Paisagem, Tempo e Cultura (pp. 84-91). Rio de Janeiro: Ed. UERJ.

» Besse, J. M (2006). Ver a Terra - seis ensaios sobre a paisagem e a geografia. São Paulo: Perspectiva.

» Bhabha, H. (2008). O local da cultura. Belo Horizonte: Editora da UFMG.

» Bustos, F., Balbiano, A., luso, R,. Hirschhorn, M. L., Migale, G. M., Perez, M. L. F., Rangoni, F., San Cristóbal, D., Snyrynskyj, G. C. e Troncoso, C. A. (2015). Geografía: espacios geográficos de América. Ciudad Autónoma de Buenos Aires: Santillana.

»Canclini, N. G. (1997). Culturas Híbridas. São Paulo: EDUSP.

" Cazetta, V. (2013). Apresentação - da política e da poética das imagens: trajetórias de história até agora. En: V. Cazetta e W. M. Oliveira Jr. (Orgs.), Grafias do Espaço: imagens da educação geográfica contemporânea (pp. 09-20). Campinas: Ed. Alínea.

" Cosgrove, D. E. e Daniels, S. (1988). Iconography of Landscape. Cambridge: Cambridge University Press.

» Daltério, L., Martin, J., López, L.E., Bembi. M., Freiman, D. R., Sposob, G., Valverde, S. e Rovatti, D. (2016). Avanza: geografía, estados y territorios del mundo. Ciudad Autónoma de Buenos Aires: Kapelusz.

"Dubois, P. (2015). El acto fotográfico y otros ensayos. Ciudad Autónoma de Buenos Aires: La Marca Editora.

» Flores, F., Maraschio F. G. e Kuper, D. (2015). Geografía 10. Espacios geográficos latino-americanos. Edición especial para el Ministerio de Educación de la Nación. Ciudad Autónoma de Buenos Aires: Longseller.

»Flores, F., Maraschio F. G. e Benitez, C. (2015). Geografía, economía y sociedad en el mundo actual. Edición especial para el Ministerio de Educación de la Nación. Ciudad Autónoma de Buenos Aires: Longseller. 
»Hanciau, N. J. (2005). Entre-Lugar. Em E. Figueiredo (Org.), Conceitos de Literatura e cultura (pp.125-142). Juiz de Fora: Editora da UFJF.

» Hall, S. (2006). Identidade Cultural na Pós-Modernidade. Rio de Janeiro: DP\&A Editora.

» Hissa, C. E. V. (2006). A mobilidade das fronteiras: inserções da geografia na crise da modernidade. Belo Horizonte: Editora UFMG.

» Hollman, V. (2014). Regimes visuais da questão ambiental nos livros didáticos de Geografia na Argentina. Revista Brasileira de Educação em Geografia, 4(8), 221-240.

» Hollman, V. e Lois, C. (2015). Geo-grafías. Imágenes e instrucción visual en la geografía escolar. Buenos Aires: Paidós.

»Lima, C. R. (2008). O uso da leitura de imagens como instrumento para a alfabetização visual. Curitiba, Cadernos PDE, 2. Disponível em: www. diaadiaeducacao.pr.gov.br/portals/cadernospde/pdebusca/producoes_ pde/2008_embap_arte_md_cristiane_rodrigues_de_lima.pdf Acessado em: 25 de maio de 2014

» Martins, J. de S. (1997). Fronteira: a degradação do outro nos confins do humano. São Paulo: Hucitec.

》 Mellado, L. A. (2008). Aproximaciones a la idea de nación: convergencias y ambivalencias de una comunidad imaginada. Alpha, 26, 29-45.

" Oliveira Jr., W. M. e Soares, E. dos S. (2012). Fotografias didáticas e Geografia escolar entre evidências e fabulações. Percursos, 13(02),114-133.

"Raffestin, C. (2005). A ordem e a desordem ou os paradoxos da fronteira. Em T. M. Oliveira (Org.), Território sem limites: estudos sobre fronteiras (pp. 09-15). Campo Grande: Ed. da UFMS.

"Said, E. (1995). Cultura e Imperialismo. São Paulo: Companhia das Letras.

» Sgubin, N. G., Bosoer, L,Escalante, S. e Calvo, M. G. L. (2015). Geografía 2. América Latina en el contexto global. Ciudad Autónoma da Buenos Aires: Tinta Fresca.

» Tagg, J. (1988). El peso de la representación. Barcelona: Editorial Gustavo Gili.

»Zapepettini, C., Nieto, D., Colombara, M., González, J., Quiñones, V. e Schujman, G. (2015). Geografía 2 provincia de Buenos Aires: la conformación del espacio latinoamericano y su situación actual. Ciudad Autónoma de Buenos Aires: Aique Grupo Editor.

» Zapepettini, C., Nieto, Colombara, M., Bidondo, A., Quiñones, V., Lara, M., Zilio, C. e Schujman, G. (2015). Geografía 3 provincia de Buenos Aires: la conformación del espacio geográfico argentino y su situación actual. Ciudad Autónoma de Buenos Aires: Aique Grupo Editor.

»Zusman, Perla. (2017). La técnica y la definición de las fronteras. Revista de Geografía Norte Grande, 66, 49-60.

Flaviana Gasparotti Nunes / flaviananunes@ufgd.edu.br

Licenciada, Mestre e Doutora em Geografia pela Universidade Estadual Paulista Júlio de Mesquita Filho, Brasil. Professora Associada (nível 3) da Universidade Federal da Grande Dourados. Coordenadora da Rede Internacional de Pesquisa "Imagens, geografias e educação". Realiza pesquisas e possui publicações sobre ensino de Geografia, linguagens e formação de professores. 